\title{
LOCAL CONTRIBUTIONS OF FORESTS TO ECONOMIC GROWTH OF PERU: A CASE OF PINUS RADIATA PLANTATIONS
}

\author{
Nadia Nora Urriola Canchari, Pradeep Baral, Lanhui Wang \\ School of Economics and Management, Beijing Forestry University, Beijing, \\ People's Republic of China
}

date of paper receipt:

11.04.2018.

Orginal article date of sending to review:

12.04.2018.

doi: 10.2478/eoik-2018-0001 date of review receipt:

20.04.2018.

UDK: 630:330.34(85)

\section{SUMMARY}

The economic contributions from forestry sector remain relatively important in all developing economies. Over the past few decades, value added in the forestry sector of these economies has gradually increased. Consequently, the need for a detailed and accurate assessment of the economic contribution of the sector has grown in order to gain the attention of the policy makers and to highlight its importance in poverty alleviation and sustainable development. Contrarily, In Peru, forestry sector continues to be left behind due to faster growth in other sectors of economy. Despite having considerable forest resources, the full extent of economic contributions of the forestry sector to local as well as the national economy is still poorly understood. Sparsity of up-to-date data on value added in the forestry sector and a general disregard to any forests other than Amazonian rainforests have compounded the already existing situation. In this context, this paper aimed at making an empirical analysis of the direct contributions of the forestry sector to the local economy of Peru in the short run using an annual time series data from 2007 to 2016. The Pinus radiata plantation forests of the Department of Ayacucho located in the Southern Peruvian Andes served as a case for this study. The results revealed nominal but significant contributions of the Pinus radiata forests to the economic growth of the Department of Ayacucho. As our study was limited only to direct cash benefits, future studies should also take into account informal and non- cash benefits in order to fully apprehend the economic contributions of the forestry sector to local and national economy.

Keywords: Ayacucho, forestry sector, economic growth, Pinus radiata, forest plantations, OLS regression, causality test

\section{INTRODUCTION}

There is a great diversity of contexts in which both conservation and destruction of tropical forests occur in the vast Asia-Pacific region. There are many actors involved (societies, governments and industries), responding to very different pressures (Byron, 1997). Therefore, it is difficult to assemble comprehensive evidence of the importance of forest products to rural people in Asia-Pacific. Data on various aspects of forests in relation to other social, economic, and institutional indicators are patchy in space and time, are very difficult to compare across countries and regions, and are insufficient as a firm basis for policy action (Agrawal et al., 2013). Byron (1997) reported that 
official statistics from the region provide little assistance, because most production, consumption and marketing of low value timber products and all non-timber forest products (NTFPs), including wood-fuel, is outside the formal economy. The absence of aggregated data on the economic contributions related to these timber and non-timber forest products and their value, and the lack of information systems that can incorporate such data systematically are major bottlenecks in a better understanding of forest sector contributions (Agrawal et al., 2013). The Asia-Pacific region in particular, it has become imperative to recognize and appropriately value the outstanding economic contributions of forests to human welfare and development in order to slow down, if not reverse, the ongoing trends and patterns of deforestation that contribute significant amount of global forest-related Green House Gas (GHG) emissions, more than sub-Saharan Africa and Latin America combined (FAO, 2010). While forest sector is seldom a priority among the major sectors of the economy for some countries of the region such as China or Australia, its contribution to the national economy and poverty alleviation can still be significant for selected developing economies such as Indonesia, Mexico or Peru (Puustjarvi, Mickels-Kokwe, \& Chakanga, 2005). Notwithstanding, incomplete valuation of forests and contribution to local as well as national economics is currently being practised because the sector often makes its input outside of the cash economy and the benefits are indirect or even intangible. This has reinforced perceptions that forests have little worth other than for their timber, which has made governments in the region assign low priority to the forestry sector (Kengen, 1997).

In Peru, a middle-income economy located in western South America bordering the South Pacific Ocean, the role of the forest sector in economic development has not yet been fully recognized. FAO (2015) estimated that $57.8 \%$ or about $73,973,000$ ha of Peru is forested. Of this $88.9 \%$ is classified as primary forest, the most biodiverse and carbon-dense form of forest. The annual rate of deforestation between 1995 and 2015 was calculated at $0.2 \%$, comparatively lower than neighbouring Brazil. However, considering only the recent period (2010 - 2015), the annual rate of deforestation for Peru was much higher $(0.3 \%)$ than Brazil, for which the rate was close to zero. While deforestation is highly context specific, changing demographics and socio-economic circumstances are frequently cited primary causes of forest loss (Geist \& Lambin, 2001). Peru, the fourth most populous country in South-America with an estimated population of 32 million, had a growth rate of 1.3\% per annum in 2016 (The World Bank, 2018b), higher than most of the South-American countries. The economy of Peru has grown in proportion to the growth in population and in concert with changes in the national economy. The per capita GDP increased three folds from USD 2,000 in 2000 to USD 6000 in 2016 (The World Bank, 2018a). From a primarily agrarian economy in the 1900s, Peru became a centre for manufacturing in South America (García-Herrero et al., 2014). More recent growth has focused on the service sectors, increasing the diversity of the economy. Through all these developments, Peru's forests have provided raw materials for both wood and non-wood based industries (Palo \& Mery, 2012). But the pattern of overall economic changes in such contributions should be a major cause of concern to forest professionals, whether that interest is related to ecological sustainability, ecosystem services, or economic benefits.

While the questions of deforestation and reforestation in Peru generally conjure images of the nation's Amazon Basin, the term is less commonly associated with Peru's Andean mountains. The Southern Peruvian Andes have many mountainsides with large stands of forest, consisting of both native and introduced species (Luzar, 2007). Much literature has addressed deforestation and forest transitions happening in the Amazons (e.g., Andersen, Granger, Reis, Weinhold, \& Wunder, 2002; Geist \& Lambin, 2001; Robertsen, 2012), however, until recently, this important phenomenon of forest cover changes have been largely overlooked in the southern Peruvian Andes. At various points in the 20th century, and especially in the late 1960s and early 1970s, the Peruvian government collaborated with peasant communities to reforest large tracts of land-most commonly with fast growing species (pine and eucalyptus) - to address a growing shortage of timber and fuel wood for the burgeoning manufacturing sector (Jobbágy, Baldi, \& Nosetto, 2011; Luzar, 2007). In the 1990s, increasingly globalized forestry markets and companies together with favourable local 
ecological (fast growth rates) and economic (low land and labour costs) conditions (Cubbage et al., 2007) propitiated a new wave of forest plantation expansion that still continues in the Peruvian Andes. Species covering the largest area of the Peruvian Andes are Eucalyptus grandis, Eucalyptus globulus and related hybrids, together with Pinus elliotti and Pinus radiata (Jobbay). Despite an initial scepticism, for example, a concern over dedicating agricultural land to an unfamiliar tree species (Oficina Nacional de Evaluacion de Recursos Naturales, 1986), plantations forests in recent decades have grown in economic and cultural importance (Luzar, 2007).

Despite their apparent and realized benefits, there is a paucity of relevant studies that link the output of forest plantations to local as well as national economies in Peru. While the contribution of overall forestry related activities to the country's GDP is well understood (Hotz \& Guarín, 2014), the sectoral contribution (e.g., from plantation forests, natural forests, mangroves etc.) to the national as well as the local economies is still elusive, and not much effort has been made to account for such contributions due to a decline in the prominence of forests compared to other sectors of economy. Agrawal et al. (2013) report that the relatively isolated nature of forestry agencies and services, including the limited exchanges between professionals in the forest and other sectors have contributed towards making forest sector less prominent economically. Limited availability of hard data and a largely outdated and fragmented statistical information has made it more difficult to assess the sector's present and potential contributions in addition to the general lack of attention towards forestry sector and sub-sectors. While challenges are prevalent elsewhere, available literature from other developed and developing economies suggest evidence of strong positive relationships between forestry sector and local economic growth (e.g., Abt, Winter, \& Huggett Jr, 2002; Barik \& Mishra, 2008; Hassan, Mbuli, \& Dlamini, 2002; Puustjarvi et al., 2005; Whiteman \& Lebedys, 2006). However, most previous studies lacked a concrete methodological approach that is simple and inexpensive, and at the same time, will appeal to governments and multilateral organizations. The focus of this investigation is to analyse the direct economic contributions of the forest sector, especially those related with Pinus radiata plantations in the Southern Andes of Peru, to the local economy of Department of Ayacucho based on existing time-series data obtained from government and sources. Our a priori assumption, based on the review of relevant literature, is a significant impact of the outputs from the existing Pinus radiata plantations to the overall economic growth of Ayacucho. Econometric models were specified and analyzed to test the validity of our assumption. The indirect and intangible benefits (e.g., value of environmental services) were excluded from the scope owing to lack of data. Extensive basic research and data collection would be needed to provide estimates on these contributions.

\section{LITERATURE REVIEW}

The economics of forestry is about land and the human activity in the forest (Hyde, 2012). Despite their popular image of stability, forests do change, in part because they are alive, and also because some of their trees are cut to satisfy societal needs that may reflect complex, long-term goals (Buongiorno, 1996). Meyer and Turner (1996) noted that human land use (both deliberately and inadvertently) alters forests in 3 ways: converting, or changing it to a qualitatively different state; modifying it or quantitatively changing its condition without full conversion; maintaining it in its condition against natural agents of change. There is a growing concern over shrinking areas of forests worldwide in the recent time (Barraclough \& Ghimire, 2000). According to FAO (2015), the global forest coverage declined from 4,128 million ha in 1990 to 3,999 million ha in 2015, representing an annual deforestation rate of $0.13 \%$. Tropical forests in particular have experienced the highest levels of deforestation (Kaimowitz, 2002; Lambin, Geist, \& Rindfuss, 2006). Given this context, the need to address the causes of forest cover loss has received increasing attention from scientists and policy makers due to increased realization of its threat to local, regional and global climate, biodiversity, and livelihoods and economy (Angelsen \& Kaimowitz, 1999; Fitzherbert et al., 2008; Karkee, 2007; 
Shukla, Nobre, \& Sellers, 1990). For understanding the dynamics of forest cover changes, the von Thünen model provides an appropriate starting point. The model focuses on land rent, based on an assumption that land is allocated to the use generating the highest land rent (surplus) (Angelsen, 2007). The rent of alternative land uses is determined by a number of factors such as crop prices, input costs, available technologies, agro-ecological conditions, etc. Many of these depend directly or indirectly on the location of the land. However, over time evidence started to indicate that in some countries, both in the north and the south, that lands that had been cleared started to show the resurgence and this phenomenon led to the birth of the forest transition theory (Mather, 1992). According to forest transition theory (FTT), one path towards reforestation is when development shifts human activities from agriculture to industry thus allowing fields to revert back to forestland (Mather, 1992; Mather, Fairbairn, \& Needle, 1999). Much as the forest transition theories uphold the demographic and economic causes of deforestation, they are seen to be optimistic in their approach compared to earlier models of von Thünen model or the Malthusian Theory (Weir, 1991) which contended that an increase in population density would lead to deforestation.

Given the widespread problem of deforestation and related forest cover changes, national and sectoral forest sector policies play key role in the sustainable management and utilization of forests, and its state in the future. According to Tikkanen (1981), organization and implementation of forest sector policies aim at maximizing the utilities produced by the forest resources now as well as in the future. The focus of forest policy goals and the mutual relationships between them vary in different countries with respect to the production of wood and other tangible forest goods, the conservation and improvement of the environment and the provision of recreational facilities. The differences in the preferences originate from the relative significance of forestry and forest industries in the national economy, or from the environmental functions the forests are serving (Tikkanen, 1981). Managing the forest to make sure that it will satisfy the diverse needs of society, contribute to the welfare of nation and at the same time provide valuable ecosystem services requires (Buongiorno, 1996). In the United States, the use of rigorous econometric methods to forecast forest product markets began in the 1950s. Pringle (1954) and Gregory (1960) did some pioneering works that led to the first generation of econometric models that had clear potential for policy studies. (McKillop (1967) developed a first model that dealt with the entire forest sector, from the supply of logs to the demand for final products. During the 1980s, forest economists were encouraged to pursue works of synthesis, i.e. complete models of sectors. Adams and Haynes (1980) collaborated to develop the timber assessment market model that dealt mostly with the solid wood. The global trade model (GTM), developed by an international team of forest economists still remains a prominent global model in the field of applied economics (Binkley, Dykstra, \& Kallio, 1987). GTM has led to discussions related to a need to avoid any single paradigm, but to exploit the best features of econometrics, operations research (Buongiorno, 1996). In conjunction with the national models, several other econometric models have been developed in the last few decades for smaller geographic areas (e.g., Brooks, 1985; Newman, 1987).

Analytical models such as von Thünen model or the Forest Transition models use theoretical constructions of the interrelationships between the factors involved. They include no empirical data, but they present theories in a rigorous framework, which allows researchers to determine the logical implications of their assumptions. They use formal mathematical equations, but these equations have only algebraic expressions, and no numbers (Kaimowitz \& Angelsen, 1998). Usually, standard mathematical techniques, such as Lagrange optimization (with equality constraints) and linear programming (with inequality constraints), are employed to solve the objective functions (Shi, 2015). Empirical statistical and econometric models, on the other hand, use statistical methods to deduce the theoretical relationships between these factors from a large number of data sets (Kaimowitz \& Angelsen, 1998). However, these approaches have also been criticised on heuristic and methodological grounds. (Perry, 2016) notes that in essence, the question to ask is 'how much can an empirical- statistical model illuminate process and causality?' Bates and Granger (1969) suggest 
combining different sources and modelling techniques in some way so that the resulting model forecasts may be more accurate than any of the individual components. Consequently, researchers are developing and applying new mathematical, statistical and computational tools to develop novel econometric time-series methods embedded in automatic modelling software to improve empirical econometric analyses and forecasting that allow to combine theoretical insights with empirical evidence to discover new results (Institute for New Economic Thinking, 2018). By retaining theory models, far larger information sets can be investigated without risking spurious findings, thereby allowing new features to be discovered when the theory-model is incomplete or incorrect.

\section{MATERIALS AND METHODS}

\section{STUDY AREA}

The study was carried out in the Department of Ayacucho, Peru that is located in the South-central Andes of the country between geo-coordinates $13^{\circ} 42^{\prime} 45^{\prime \prime} \mathrm{S}$ latitude and $74^{\circ} 02^{\prime} 03^{\prime \prime} \mathrm{W}$ longitude (Figure 1). With an area of $43,814.8 \mathrm{~km}^{2}$, the Department of Ayacucho covers approximately $3.5 \%$ of the total land area of Peru. Its capital is the city of Ayacucho. Over $90 \%$ of the Department belongs to the Andean highlands. The elevation ranges between $-473 \mathrm{~m}$ above sea level (MASL) at the lowest point to 7,444 m MSAL at the highest point. The climate varies depending on the altitude and agro-ecoregions. 6 of the 8 agro-ecoregions in Peru are found in the Department of Ayacucho. The main characteristic of the climate in the area is the temperate climate with a temperature of $20^{\circ} \mathrm{C}$ during the day and $10^{\circ} \mathrm{C}$ during the night. The average temperature is between $11^{\circ} \mathrm{C}$ and $16^{\circ} \mathrm{C}$, the highest temperature is between $22^{\circ} \mathrm{C}$ and $29^{\circ} \mathrm{C}$, and the lowest temperature is between $-7^{\circ} \mathrm{C}$ and $-4^{\circ} \mathrm{C}$. Annual precipitation averages $450 \mathrm{~mm}$.

According to the 2005 census, the total population of the Department was estimated to be 619,552 with a population density of $14 / \mathrm{km}^{2}$. The region has a high incidence of poverty at $72.5 \%$, highest for any Departments of Peru. The nominal contribution of the Department to the national GDP is only $0.65 \%$, the lowest contribution among all other Departments in the country. The main income source of the population in the Department is agriculture and the major farm products are potatoes, wheat, barley, and sheep meat. The Department was one of the hardest hit by terrorism during the 1980s during the guerrilla war waged by Shining Path known as the internal conflict in Peru (Fumerton, 2001).

High montane forests (Young \& León, 1999) or subtropical yungas (Zamora, 1996) of the Department are characterized by high species diversity and endemism of the flora and fauna. In terms of mammals, this region holds $60 \%$ of all endemic species in the country (39 species), most of which are rodents. Forests of Ayacucho are considered a unique but, at the same time, very fragile ecosystem because of the fast rate of habitat degradation by human activities, and therefore, they are considered one of the 18 priority terrestrial ecoregions for conservation (Mittermeier, Myers, Mittermeier, \& Robles, 1999). Primarily due to smallholder peasant's logging activities, Ayacucho lost 9,842 ha of forest between 2001 and 2015 (INEI, 2015). 


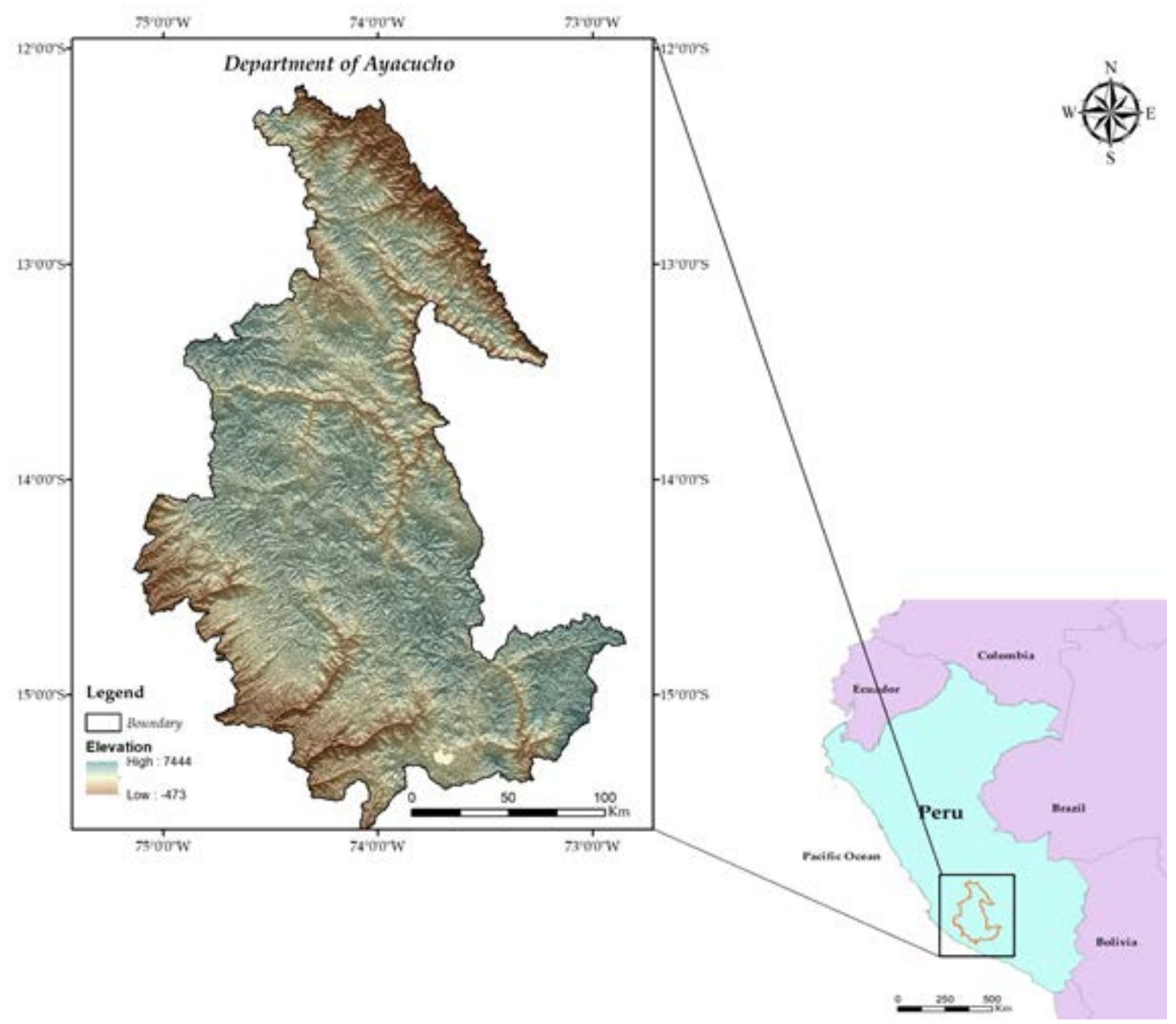

Figure 1 Location Map of the Department of Ayacucho in Peru

\section{RESEARCH DESIGN}

This research was fundamentally analytical and descriptive as it embraced the use of secondary data to determine the effect of the forest sector through the benefits from Pinus radiata on the economic growth of Ayacucho, in a short run. For the analytical test, we used various econometric tests for modeling the annual time series data. For descriptive analysis, we used the ordinary least square regression.

\section{KINDS AND SOURCES OF DATA}

For the current research, we needed an annual time series data that covered the period between 2007 - 2016 including, data on Gross Domestic Product (GDP) of Ayacucho, data on the forest and agriculture sector of Ayacucho (as value added) to the GDP from Ayacucho and benefits from the production of Pinus radiata. The data for this research was obtained from different national sources depending on the availability. In the case of the GDP and the forest and agriculture sector of Ayacucho, the sources were Peruvian Central Bank of Reserve (PCBR) and their annual reports, and the National Institute of Statistic. In the case of the benefits of pine production, the source was the Municipality of Victor Fajardo Province. 


\section{MODEL SPECIFICATION}

In order to examine the contribution of the forest and agriculture sector of Ayacucho to the economic growth of Ayacucho, the model was specified as following:

GDPAY $_{\mathrm{t}}=\mathrm{f}\left(\mathrm{FAGDPAY} \mathrm{F}_{\mathrm{t}}\right.$,

To discard the differences in the measurement units, natural logarithm was applied on both sides of the equation 1, for the minimization of the gap between the dependent and independent variables. LGDPAY $_{\mathrm{t}}=\beta_{0}+\beta_{1}$ LFAGDPAY $_{\mathrm{t}}+\mathrm{e}_{\mathrm{t}}$

Where:

$\begin{array}{ll}\text { LGDPAY }= & \text { Natural logarithm of the Gross Domestic Product of Ayacucho. } \\ \text { LFAGDPAY } & \text { Natural logarithm of Forest and Agriculture Sector of Ayacucho, as value } \\ & \text { added to the GDP. } \\ = & \text { Error term } \\ e_{t} & \text { Constant term } \\ \beta_{0} & =\text { Parameters of explanatory variables estimated in the model } \\ \beta_{1} & \end{array}$

In order to examine the contribution of the benefits from the Pinus radiata to forest sector growth supply-side perspective, the model was specified as following:

FAGDPAY $_{\mathrm{t}}=\mathrm{f}\left(\mathrm{BPINE}_{\mathrm{t}}\right)$,

To discard the differences in the measurement units, natural logarithm was applied on both sides of the equation 3, for the minimization of the gap between the dependent and independent variables.

LFAGDPAY $=\beta_{0}+\beta_{1}$ LBPINE $_{\mathrm{t}}+\mathrm{e}_{\mathrm{t}}$,

Where:

$\begin{array}{ll}\text { LFAGDPAY } & \text { Natural logarithm of Forest and Agriculture Sector of Ayacucho, as value } \\ & \text { added to the GDP. } \\ \text { LBPINE } & =\text { Natural logarithm of the benefits from Pinus radiata. } \\ \mathrm{e}_{\mathrm{t}} & \text { Error term } \\ \beta_{0} & =\text { Constant term } \\ \beta_{1} & =\text { Parameters of explanatory variables estimated in the model }\end{array}$

\section{ESTIMATION PROCEDURES}

In this case, for the short run analysis, regression for the multivariable series was used, and enforced for the Unit Root Test and the Causality Test.

\section{UNIT ROOT TEST}

The usage of ordinary least squares (OLS) regression analysis on time series data usually requires that the data should be stationary to avoid the problem of spurious regression. A variable is considered as stationary if it has a constant mean, variance and auto covariance at any measured point. A non-stationary time series may become stationary after differencing a number of times. In the case the series is not stationary at the base level, it would be stationary after successive differencing. The order of integration of a series is the number of times it needs to be differenced to become stationary. A series integrated of order I ( $\mathrm{n}$ ) becomes stationary after differencing $\mathrm{n}$ times. In this study, the stationary test was carried out using the Augmented Dickey-Fuller (ADF) test, which was formulated by Dickey and Fuller (1979). The decision rule states the series is stationary if the ADF test statistic is greater than the critical value, and that it isn't stationary if it is less than the critical value. The general ADF Test form is represented by the following regression: 


$$
\begin{aligned}
& \qquad \mathrm{Y}_{\mathrm{t}}=\alpha_{0}+\alpha_{1} \mathrm{Y}_{\mathrm{t}-1}+\sum_{\mathrm{n}=1}^{\mathrm{N}} \alpha \Delta \mathrm{Y}_{\mathrm{i}}+\mathrm{e}_{\mathrm{t}} ; \text { it includes only drift, } \\
& \Delta \mathrm{Y}_{\mathrm{t}}=\alpha_{0}+\alpha_{1} \mathrm{Y}_{\mathrm{t}-1}+\sum_{\mathrm{n}=1}^{\mathrm{N}} \alpha \Delta \mathrm{Y}_{\mathrm{i}}+\delta_{\mathrm{t}}+\mathrm{e}_{\mathrm{t}} ; \text { it includes only the drift, } \\
& \text { Where: }
\end{aligned}
$$

$\begin{array}{ll}\mathrm{Y} & =\text { Time series of specified variable } \\ \mathrm{t} & =\text { Time trend } \\ \Delta & =\text { First differencing operator } \\ \mathrm{a}_{0} & =\text { Constant term } \\ \mathrm{N} & =\text { Optimum lags' number } \\ \mathrm{e}_{\mathrm{t}} & =\text { Random error term }\end{array}$

\section{PAIRWISE GRANGER CAUSALITY TEST}

To examine the significant causality relationship of the forest and agriculture sector (as value added) to the GDP from Ayacucho with the economic growth in Ayacucho; and of the benefits from Pinus radiata production with the forest and agriculture sector (as value added) to the GDP from Ayacucho, Granger Causality Test (Bates \& Granger, 1969) was performed. The independent variable is considered as a Granger-cause variable of $Y$, if the $y_{t}$ (the variable $Y$ in the current period) is conditional on the past values of the variable $\mathrm{X}\left(\mathrm{x}_{\mathrm{t}-1}, \mathrm{x}_{\mathrm{t}-2}, \mathrm{x}_{\mathrm{t}-1} \ldots \mathrm{x}_{0}\right)$.

Focusing on the forest and agriculture sector of Ayacucho as the engine of the economic growth of Ayacucho, we were interested in the bidirectional causal relationship between the two to provide evidence of that independent variable as the cause of the economic growth of Ayacucho between 2007 and 2016. Therefore, we considered the following Hypothesis:

For the case of LGDPAY (Natural logarithm of the Gross Domestic Product of Ayacucho) and LFAGDPAY (Natural logarithm of Forest and Agriculture Sector as value added to the GDP from Ayacucho):

\section{i. LGDPAY does not Granger Cause LFAGDPAY \\ ii. LFAGDPAY does not Granger Cause LGDPAY}

And, focusing on the benefits of Pinus radiata production as the engine of the forest and agriculture sector growth of Ayacucho, were interested in the bidirectional causal relation between the two to provide evidence of that independent variable as the cause of the economic growth of Ayacucho between 2007 and 2016. Therefore, in this case, we considered the following Hypothesis:

For the case of LFAGDPAY (Natural logarithm of Forest and Agriculture Sector as value added to the GDP from Ayacucho) and LBPINE (Natural logarithm of the benefits from Pinus radiata):

i. LFAGDPAY does not Granger Cause LBPINE

ii. LBPINE does not Granger Cause LFAGDPAY

\section{RESULTS AND DISCUSSION}

\section{EMPIRICAL RESULTS}

Before the comprehensive econometric analysis, it is necessary for a brief interpretation of statistical analysis. The definitions and summary of the statistics of those variables are provided in Table 1, which reported that the average of the GDP growth in Ayacucho was USD ${ }^{1} 1.6$ billion with USD 445 million as the standard deviation. In the case of the combined forest and agriculture sector growth as value added to the GDP from Ayacucho, the average was USD 260.5 million and the standard deviation was USD 46.3 million. Finally, the benefit of pine production had a mean value of USD 623,957 and a deviation standard of USD 487,547.

${ }^{1} 1$ USD $=3.24$ local currency (Peruvian Sol) in 2018 
Table 1 Summary Statistics of variable, from 2007 - 2016.

\begin{tabular}{|l|l|l|l|l|l|l|l|}
\hline Variable & $\begin{array}{l}\text { Mean } \\
(\mathbf{1 0 0 0} \text { USD })\end{array}$ & $\begin{array}{l}\text { Median } \\
(\mathbf{1 0 0 0} \text { USD })\end{array}$ & $\begin{array}{l}\text { Max } \\
(\mathbf{1 0 0 0} \text { USD })\end{array}$ & $\begin{array}{l}\text { Min } \\
(\mathbf{1 0 0 0} \text { USD })\end{array}$ & $\begin{array}{l}\text { Std.Dev. } \\
(\mathbf{1 0 0 0} \text { USD })\end{array}$ & Skewness & Kurtosis \\
\hline GDPAY & $1,620,370$ & $1,694,444$ & $2,209,877$ & 919,753 & 444,444 & -0.25 & 1.73 \\
\hline FAGDPAY & 260,185 & 258,951 & 314,815 & 176,543 & 46,296 & -0.34 & 1.94 \\
\hline BPINE & 624 & 505 & 1,517 & 85 & 487 & 0.61 & 2.12 \\
\hline
\end{tabular}

Source: Researcher's compilation from Stata 13.0

For the measure and the direction of skewness (which gives the measure of departure from symmetry), a skewness analysis was carried out. While the GDP of Ayacucho and the forest and agriculture sector as value added to the GDP from Ayacucho presented an approximately symmetric distribution, the benefits of pine production showed a moderately skewed distribution.

The result of the regression equation (2), which showed the relation between the GDP of Ayacucho and the forest and agriculture sector as value added to the GDP from Ayacucho, is shown in Table 2. It indicated that this function best fitted the model with significant effects on the GDP of Ayacucho, having $84.18 \%$ as the $\mathrm{R}^{2}$ and $82.20 \%$ as the adjusted $\mathrm{R}^{2}$. This result implied that the independent variable explained the $82.20 \%$ of the total variation in the GDP of Ayacucho. The F-statistic was 0.0002 that indicated the significance, which implied that the parameters were significant at $5 \%$ even at $1 \%$. The Durbin Watson was acceptable because it's more than the superior limit 1.31971 (1.68) that also supported the OLS regression.

Table 2 Regression results (LGDPAY and LFAGDPAY)

\begin{tabular}{|l|l|l|l|}
\hline Variable & Coefficient & t-Statistic & P-value \\
\hline LFAGDPAY & 1.453296 & 6.520 & 0.000 \\
\hline CONSTANT & -7.503068 & -1.640 & 0.140 \\
\hline R-squared & \multicolumn{3}{|c|}{0.841800} \\
\hline Adjusted R-squared & \multicolumn{3}{|c|}{0.822000} \\
\hline Prob (F-statistics) & \multicolumn{3}{|c|}{0.000200} \\
\hline Durbin-Watson stat & \multicolumn{3}{|c|}{1.681027} \\
\hline
\end{tabular}

Source: Researcher's compilation from Stata 13.0

So, the equation for the model defined in the equation (2) was given as:

LGDPAY $_{\mathrm{t}}=-7.503068+1.453296 *$ LFAGDPAY $_{\mathrm{t}}+\mathrm{e}_{\mathrm{t}}$,

According to this equation, the increase in $1 \%$ of the Forest and Agriculture Sector of Ayacucho (LFAGDPAY) led to an increase of $1.45 \%$ in the Gross Domestic Product of Ayacucho (LGDPAY). It also showed if the Forest and Agriculture Sector of Ayacucho didn't have an increase, the GDP of Ayacucho would decrease in $7.50 \%$.

The result of the regression equation (4), which showed the relation between the forest and agriculture sector as value added to the GDP from Ayacucho with the benefits of pine production, was shown in Table 3. It indicated that this function best fitted the model with significant effects on the forest and agriculture sector of Ayacucho, having $86.67 \%$ as the $\mathrm{R}^{2}$ and $84.99 \%$ as the adjusted $\mathrm{R}^{2}$. This implied that the independent variable explained $85.00 \%$ of the total variation in the forest and agriculture sector as value added to the GDP from Ayacucho. The F-statistic value of 0.0001 indicated the significance, which implied that the parameters were significant at $5 \%$ even at $1 \%$. The Durbin Watson was acceptable because it is more than the superior limit 1.31971 (2.04) that also supported the OLS regression. 
Table 3 Regression results (LFAGDPAY and LBPINE)

\begin{tabular}{|l|l|l|l|}
\hline Variable & Coefficient & t-Statistic & P-value \\
\hline LBPINE & 0.182180 & 7.210 & 0.000 \\
\hline CONSTANT & 17.956290 & 50.050 & 0.000 \\
\hline R-squared & \multicolumn{3}{|c|}{0.866600} \\
\hline Adjusted R-squared & \multicolumn{3}{|c|}{0.849900} \\
\hline Prob (F-statistics) & \multicolumn{3}{|c|}{0.000100} \\
\hline Durbin-Watson stat & \multicolumn{3}{|c|}{2.037874} \\
\hline
\end{tabular}

Source: Researcher's compilation from Stata 13.0

So, the equation for the model defined in the equation (4) can be given as:

LFAGDPAY $_{\mathrm{t}}=17.956290+0.182180 *$ LBPINE $_{\mathrm{t}}+\mathrm{e}_{\mathrm{t}}$

According to this equation, the increase in $1 \%$ of the benefit of pine production (LBPINE) led to an increase of $1.45 \%$ in the Forest and Agriculture Sector as value added to the GDP from Ayacucho (LFAGDPAY). It also showed if there was no benefit from the pine production, the Forest and Agriculture sector as value added to the GDP from Ayacucho would have an increase of $17.96 \%$.

\section{UNIT ROOT TEST RESULTS}

Augmented Dickey-Fuller test was performed on all variables (gross domestic product of Ayacucho, forest and agriculture sector as value added to the GDP from Ayacucho and benefits of pine production). The results of Augmented Dickey-Fuller test for showing the existence of unit root of once differenced data were represented in Table 4.

Table 4 Unit root test for order of integration of variables (ADF)

\begin{tabular}{|c|c|c|c|c|c|c|c|}
\hline \multirow{2}{*}{ Variables } & \multirow{2}{*}{ At Level } & \multirow{2}{*}{$\begin{array}{c}\text { First } \\
\text { difference }\end{array}$} & \multicolumn{3}{|c|}{ Critical values (\%) } & \multirow{2}{*}{ Probability } & \multirow{2}{*}{$\begin{array}{c}\text { Order of } \\
\text { Integration }\end{array}$} \\
\hline & & & 1 & 5 & 10 & & \\
\hline LGDPAY & -4.103 & & -3.750 & -3.000 & -2.630 & 0.0010 & $\mathrm{I}(0)$ \\
\hline LFAGDPAY & -3.536 & & -4.380 & -3.600 & -3.240 & 0.0357 & $\mathrm{I}(0)$ \\
\hline LBPINE & -23.151 & & -3.750 & -3.000 & -2.630 & 0.0000 & $\mathrm{I}(0)$ \\
\hline
\end{tabular}

Source: Researcher's compilation from Stata 13.0

The reported result in Table 4 confirmed the stationary test of the variables at the level form I (0) for the LGDPAY, LFAGDPAY and for the LBPINE. According to this, the null hypothesis of non-stationary could be rejected at $5 \%$ and $10 \%$ critical value level confirming that the ADF test statistics was greater than the critical value, which also could be understood as the P-value was significant at the level form I (0) because it is less than 0.05. Since the null hypothesis was rejected for all the variables at a convenient significant level, the variables did not have a unit root at levels. Therefore, we could conclude that the variables data were stationary at the level of order one I (0). Those stationary tests supported the econometric model of the equation (7) and equation (8).

\section{GRANGER CAUSALITY TEST RESULTS}

We analyzed the causal relationship between LGDPAY (Natural logarithm of the Gross Domestic Product of Ayacucho) and LFAGDPAY (Natural logarithm of Forest and Agriculture Sector as value added to the GDP from Ayacucho); and the causal relationship between LFAGDPAY (Natural logarithm of Forest and Agriculture Sector as value added to the GDP from Ayacucho) and LBPINE (Natural logarithm of the benefits from Pinus radiata) using Granger (1969) Causality Test. The Table 5 showed that value of the Test considering the probability value of $5 \%$. 
Table 5 Pairwise Granger Causality Test

\begin{tabular}{|l|l|l|}
\hline Null hypothesis & F-statistic & Prob. \\
\hline LGDPAY does not Granger Cause LFAGDPAY & 0.000039 & 0.995 \\
\hline LFAGDPAY does not Granger Cause LGDPAY & 7.402200 & 0.007 \\
\hline LFAGDPAY does not Granger Cause LBPINE & 6.500000 & 0.011 \\
\hline LBPINE does not Granger Cause LFAGDPAY & 0.018380 & 0.892 \\
\hline
\end{tabular}

Source: Researcher's compilation from Stata 13.0

The result for the causal relationship between LGDPAY (Natural logarithm of the Gross Domestic Product of Ayacucho) and LFAGDPAY (Natural logarithm of Forest and Agriculture Sector as value added to the GDP from Ayacucho) showed it was unidirectional, while the LGDPAY did not reveal to have an influence on the LFAGDPAY, the LFAGDPAY had an influence on the LGDPAY. For the case of the LFAGDPAY (Natural logarithm of Forest and Agriculture Sector as value added to the GDP from Ayacucho) and the LBPINE (Natural logarithm of the benefits from Pinus radiata), it was demonstrated that there was also a unidirectional causal relationship between them, where the LFAGDPAY Granger caused the LBPINE. The results showed that the Forest and Agriculture sector of Ayacucho caused the economic growth of Ayacucho, and the forest and agriculture sector growth of Ayacucho caused the benefits of pine production.

\section{CONCLUSION AND RECOMMENDATIONS}

Over the past millennia, economic contributions from forests to household economies, community livelihoods, national incomes, and global output have been consequential to the continued economic development. The importance of properly recognizing the role of forests in sustainable development, and local green economy and poverty eradication could not be overstated. Notwithstanding, the general lens through which forests are viewed by national and international agencies continue to be a holdover from colonial times promoting visions of forests as resources to be mined in perpetuity for the short run financial returns. This is more evident in the southern Peruvian Andes, where the complex nexus of forestry, poverty and economic development had been disregarded for centuries until recently when local governments started large scale plantations development in order to improve the livelihoods of the rural poor and meet the timber demand of the burgeoning manufacturing industries. In this context, the aim of the present study was to make an empirical analysis on the direct contribution of forest sector, especially those related with Pinus radiata plantations in the Southern Andes of Peru, to the economic growth of Department of Ayacucho in the short run using an annual time series data from 2007 to 2016. Several econometric models were specified for the analysis. In particular, ADF Test that was used to determine the stationary characteristics of the data showed all determinants achieved stationary at the level I (0) supporting the regression model used for the short run analysis. The analysis revealed a positive relationship between the forest and agriculture sector growth and the economic growth of the Department, and between the benefits from Pinus radiata production and the forest and agriculture sector growth. Moreover, Granger Causality test revealed a unidirectional causality relationship between forest and agriculture sector and the GDP of the Department. A unidirectional causal relationship between benefits from Pinus radiata production and forest and agriculture sector of Ayacucho Department was also uncovered doing the analysis. In the first case, the forest and agriculture sector caused a growth in the GDP of the Department, while in the second case the benefit from Pinus radiata production didn't cause the forest and agriculture sector growth of the Department. These results are not surprising because people in Ayacucho Department have depended since ancient times on forestry and agricultural activities, the main reason for which the local government has 
been investing heavily in plantation and reforestation projects in the region with participation from the local peasant communities.

In Peru, forestry sector has seen notable development in the past few decades, due to reduction of natural forests cover and the expansion of forest plantations of exotic species. The expansion of forest plantations and the wood based industries has gained forestry sector a relevant role in local and national economy, and a global position in the wood market. While there are many benefits that Peru and its local Departments derive from forest plantations, there are also costs associated that are often ignored as they are primarily borne by the rural poor sited in the plantation areas. Experience from Peru as well as other South American countries has shown that forest plantations establishment often leads to displacement of small indigenous communities rendering them landless. At the same time, there is a growing concern that job creation through tree plantations is irregular and cannot sustain rural livelihood development. Furthermore, large scale plantations are cited as one of the major cause for rural depopulation, loss of social capital, agriculture land abandonment, and other local social and environmental problems. At national context, a strong neoliberal economic strategy has paved the way for a model of export-led growth through extraction of existing natural resources, this development has also brought some remarkable transformations in land use through large scale plantation developments in existing natural forests areas with some regional and global consequences. It is therefore important to consider important environmental, social and economic externalities, at local, national and regional scale, resulting from such large scale forest plantations. A proper realization of the externalities, in addition to direct and indirect cash and non-cash benefits from the forest plantations would only make a study about their economic contributions meaningful.

In conclusion, our study demonstrated an efficient and practical approach to analyze the direct economic contributions of the forest sector to the local economy in regions that are marginalized from the mainstream development processes, and where relevant researches are sparse. Attempts such as those undertaken in this paper to develop a systematic assessment of the economic contributions of forests run up against persistent problems of data availability common in the developing nations. The data on various aspects of forests in relation to other social, economic, and institutional indicators are patchy in space and time, are very difficult to compare across different geographic regions, and are insufficient as a firm basis for policy action. Available data allow only a blurry picture of the extent of positive externalities and non-cash economic benefits forests provide that is not sufficient to allow the inference, against the commonly hold belief, that non-cash forest benefits are far larger than those derived from the tangible forest products that are exchanged in market. Therefore, further studies focus not only on the contributions of direct, cash benefits from forest products but also the non-cash and informal benefits forest generate through non-wood forest products, biodiversity conservation, carbon sequestration, hydrological regulation, and similar other ecosystem services. Forest agencies, in particular, should invest considerable efforts in order to collect data on non-cash and informal benefits in addition to the social, economic and environmental externalities forests generate. This could be achieved through collaboration across different sectoral agencies to integrate datasets, and make them publicly available through web-hosting or other forms of data dissemination in order to improve research and sharing in forestry. Areas that have historically been marginalized by the research community due to lack of relevant data would greatly benefit from such endeavors. Furthermore, within forestry sector, sub-sectors such as plantation forests and agro-forests require greater attention and further research in order to elevate the benefits from these sectors to livelihoods of local communities, and to the regional and national economy. While doing so, an interdisciplinary approach, taking into account the externalities from individual sub-sector, is essential. Measures as such would only ensure that the economic contribution from forestry sector will be in sizable proportion against contribution from other sectors of the economy to the overall economy of the nation. 


\section{REFERENCES}

Abt, K. L., Winter, S. A., \& Huggett Jr, R. J. (2002). Local economic impacts of forests. In D. N. Wear \& J. G. Greis (Eds.), Southern forest resource assessment (pp. 239-267). Asheville, NC, USA: U.S. Department of Agriculture, Forest Service, Southern Research Station.

Adams, D. M., \& Haynes, R. W. (1980). The 1980 softwood timber assessment market model: structure, projections, and policy simulations. Forest Science, 26(3), a0001-z0001.

Agrawal, A., Cashore, B., Hardin, R., Shepherd, G., Benson, C., \& Miller, D. (2013). Economic Contributions of Forests. In United Nations Forum on Forests Tenth Session 8-19 April 2013 (p. 132). Istanbul, Turkey.

Andersen, L. E., Granger, C. W., Reis, E. J., Weinhold, D., \& Wunder, S. (2002). The dynamics of deforestation and economic growth in the Brazilian Amazon. New York, NY, USA: Cambridge University Press.

Angelsen, A. (2007). Forest cover change in space and time: combining the von Thünen and forest transition theories (Vol. 4117). World Bank Publications.

Angelsen, A., \& Kaimowitz, D. (1999). Rethinking the causes of deforestation: lessons from economic models. The World Bank Research Observer, 14(1), 73-98.

Barik, S. K., \& Mishra, S. K. (2008). Assessment of the contribution of forests to the economy of the northeastern states of India. International Forestry Review, 10(2), 349-361.

Barraclough, S. L., \& Ghimire, K. B. (2000). Agricultural expansion and tropical deforestation: poverty, international trade and land use (p. 150). Abington, UK: Routledge.

Bates, J. M., \& Granger, C. W. (1969). The combination of forecasts. Journal of the Operational Research Society, 20(4), 451-468.

Binkley, C. S., Dykstra, D. P., \& Kallio, M. J. (Eds.). (1987). The global forest sector: an analytical perspective. John Wiley \& Sons.

Brooks, D. J. (1985). Public policy and long-term timber supply in the South. Forest Science, 31(2), 342-357.

Buongiorno, J. (1996). Forest sector modeling: a synthesis of econometrics, mathematical programming, and system dynamics methods. International Journal of Forecasting, 12(3), 329-343.

Byron, R. (1997). Asia-pacific forestry sector outlook study (Working Paper no. APFSOS/WP/09). Rome, Italy: Food and Agricultural Organization of the United Nations (FAO).

Cubbage, F., Mac Donagh, P., Júnior, J. S., Rubilar, R., Donoso, P., Ferreira, A., ... Balmelli, G. (2007). Timber investment returns for selected plantations and native forests in South America and the Southern United States. New Forests, 33(3), 237-255.

Dickey, D. A., \& Fuller, W. A. (1979). Distribution of the estimators for autoregressive time series with a unit root. Journal of the American Statistical Association, 74(366a), 427-431.

FAO. (2010). Forests and Climate Change in the Asia-Pacific Region (Forests and Climate Change Working Paper 7). Rome, Italy: Food and Agricultural Organization of the United Nations (FAO).

FAO. (2015). Global Forest Resources Assessment 2015. Rome, Italy: Food and Aarucultural Organization of the United Nations (FAO).

Fitzherbert, E. B., Struebig, M. J., Morel, A., Danielsen, F., Brühl, C. A., Donald, P. F., \& Phalan, B. (2008). How will oil palm expansion affect biodiversity? Trends in Ecology \& Evolution, 23(10), 538-545.

Fumerton, M. (2001). Rondas Campesinas in the Peruvian Civil War: Peasant Self-defence Organisations in Ayacucho. Bulletin of Latin American Research, 20(4), 470-497.

García-Herrero, A., Dos Santos, E., Urbiola, P., Dal Bianco, M., Soto, F., Hernández, M., ... Sánchez, R. (2014). Competitiveness in the Latin American manufacturing sector: trends and determinants. Madrid, Spain: BAVA Research.

Geist, H. J., \& Lambin, E. F. (2001). What drives tropical deforestation? LUCC Report Series, 4, 116. Gregory, R. G. (1960). A statistical investigation of factors affecting the market for hardwood flooring. 
Forest Science, 6(2), 123-134.

Hassan, R. M., Mbuli, P., \& Dlamini, C. (2002). Natural resource accounts for the state and economic contribution of forests and woodland resources in Swaziland. Pretoria, South Africa: University of Pretoria.

Hotz, H., \& Guarín, A. (2014). Fact sheet:Fact sheet: Estimating the Economic Value of Peru'sForest Sector - Beyond Conventional Wisdom (p. 8). Seoul, Republic of Korea: Global Green Growth Institute (GGGI).

Hyde, W. F. (2012). The pattern of forestry in the ocuse of economic development. In W. F. Hyde (Ed.), Global Economics of Forestry (pp. 13-63). Routledge, New York, NY, USA: RFF Press.

INEI. (2015). Perú: Anuario de Estadísticas Ambientales 2015. Jesús María, Lima, Peru: Instituto Nacional de Estadística e Informática (INEI). (in Spanish)

Institute for New Economic Thinking. (2018). Economic Modelling. Retrieved April 10, 2018, from https://www.inet.ox.ac.uk/programmes/emod/

Jobbágy, E. G., Baldi, G., \& Nosetto, M. D. (2011). Tree plantation in South America and the water cycle: impacts and emergent opportunities. In Forests in Development: A Vital Balance (pp. 53-63). Springer.

Kaimowitz, D. (2002). Amazon deforestation revisited. Latin American Research Review, 37(2), 221235.

Kaimowitz, D., \& Angelsen, A. (1998). Economic models of tropical deforestation: a review. Bogor, Indonesia: Centre for International Forestry Research.

Karkee, K. (2007). Effects of Deforestation on Tree Diversity and Livelihoods of Local Community A Case Study from Nepal. http://digitalrepository.unm.edu/nsc_research/60

Kengen, S. (1997). Forest valuation for decision-making: lessons of experience and proposals for improvement. Rome, Italy: Food and Agricultural Organization of the United Nations (FAO).

Lambin, E. F., Geist, H., \& Rindfuss, R. R. (2006). Introduction: local processes with global impacts. In Land-use and land-cover change (pp. 1-8). Springer.

Luzar, J. (2007). The political ecology of a "forest transition": Eucalyptus forestry in the southern Peruvian Andes. Ethnobotany Research \& Applications, 5, 85-93.

Mather, A. S. (1992). The forest transition. Area, 367-379.

Mather, A. S., Fairbairn, J., \& Needle, C. L. (1999). The course and drivers of the forest transition: the case of France. Journal of Rural Studies, 15(1), 65-90.

McKillop, W. (1967). Supply and demand for forest products-an econometric study. Hilgardia, 38(1), $1-132$.

Meyer, W. B., \& Turner, B. (1996). Land-use/land-cover change: challenges for geographers. GeoJournal, 39(3), 237-240.

Mittermeier, R. A., Myers, N., Mittermeier, C. G., \& Robles, G. (1999). Hotspots: Earth's biologically richest and most endangered terrestrial ecoregions. Mexico City, Mexico: CEMEX, SA, Agrupación Sierra Madre, SC.

Newman, D. H. (1987). An econometric analysis of the southern softwood stumpage market: 19501980. Forest Science, 33(4), 932-945.

Oficina Nacional de Evaluacion de Recursos, \& Naturales. (1986). Inventario y Evaluacion de los Recursos Naturales de la Zona Alto Andina del Peru-Reconocimiento. Lima, Peru: Departmento de Cusco. (in Spanish)

Palo, M., \& Mery, G. (2012). Sustainable Forestry Challenges for Developing Countries. Springer Science \& Business Media.

Perry, G. L. W. (2016). Modelling and Simulation. In N. Castree, D. Demeritt, D. Liverman, \& B. Rhoads (Eds.), A companion to environmental geography. Hoboken, NJ, USA: Wiley-Blackwell, John Wiley \& Sons.

Pringle, S. (1954). An econometric analysis of the demand for newsprint in the United States (PhD Thesis). Syracuse University, New York, NY, USA. 
Puustjarvi, E., Mickels-Kokwe, G., \& Chakanga, M. (2005). The contribution of the forest sector to the national economy and poverty reduction in Zambia. Lusaka, Zambia: Forestry Department, Zambia and Ministry for Foreign Affairs of Finland.

Robertsen, C. (2012). Forest transition or just deforestation? Evidence from Brazil. (Master's Thesis). Norwegian University of Life Sciences, Norway.

Shi, M. (2015). Forest cover change in Northeast China during the period of 1977-2007 and its driving forces (PhD Thesis). Michigan State University, East Lansing, MI, USA.

Shukla, J., Nobre, C., \& Sellers, P. (1990). Amazon deforestation and climate change. Science, 247(4948), 1322-1325.

The World Bank. (2018a). GDP per capita (current US\$). Retrieved February 16, 2018, from https:// data.worldbank.org/indicator/NY.GDP.PCAP.CD?locations $=P E$

The World Bank. (2018b). Population growth (annual \%). Retrieved February 16, 2018, from https:// data.worldbank.org/indicator/SP.POP.GROW

Tikkanen, I. (1981). Effects of public forest policy in Finland: an economic approach to empirical policy analysis. Silva Fennica, 15(1), 31-64.

Weir, D. R. (1991). Malthus's theory of population. In J. Eatwell, M. Milgate, \& P. Newman (Eds.), The World of Economics (pp. 401-406). Springer International Publishing AG.

Whiteman, A., \& Lebedys, A. (2006). The contribution of the forestry sector to African economies. International Forestry Review, 8(1), 31-43.

Young, K. R., \& León, B. (1999). Peru's humid eastern montane forests: An overview of their physical settings, biological diversity, human use and settlement, and conservation needs. Centre for Research on the Cultural and Biological Diversity of Andean Rainforests (DIVA).

Zamora, C. (1996). Las Regiones Ecológicas del Perú-Mapa. Diversidad Biológica Del Perú: Zonas Prioritarias Para Su Conservación. INRENA, GTZ. Lima, Perú. (in Spanish) 